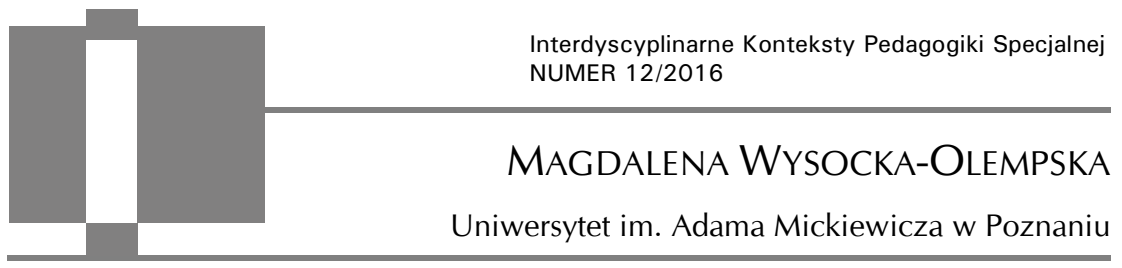

\title{
Sprawozdanie z XII Międzynarodowej Konferencji Naukowej "O nauki zaangażowane - w praktykę edukacji, rehabilitacji i socjalizacji osób z niepełnosprawnością" Ustroń, 18-19 kwietnia 2016 r.
}

18-19 kwietnia 2016 r. w Ustroniu odbyła się już XII międzynarodowa konferencja naukowa organizowana przez Zakład Pedagogiki Specjalnej Uniwersytetu Śląskiego w Katowicach, Wydział Etnologii i Nauk o Edukacji w Cieszynie. Tegoroczna konferencja skoncentrowała dyskusję wokół rzeczywistej i możliwej roli interdyscyplinarnej wiedzy o niepełnosprawności w kreowaniu praktyk edukacyjnych, rehabilitacyjnych i społecznych. Podkreślając jednocześnie zaangażowanie nauk (nie tylko pedagogiki specjalnej, ale także dyscyplin pokrewnych podejmujących problematykę niepełnosprawności) w proces diagnozowania rzeczywistości i konstruowania teorii oraz koncepcji (zwłaszcza tych wyprowadzonych z praktyki), ale także zaangażowania naukowców $\mathrm{w}$ zmianę sytuacji społecznej i edukacyjnej osób z niepełnosprawnością. Podstawowym założeniem organizatorów było podkreślenie istotności problematyki $\mathrm{w}$ aspekcie permanentnego ignorowania głosu pedagogów w konstruowaniu edukacyjnej i socjalizacyjnej rzeczywistości osób z niepełnosprawnością.

Pierwszy dzień konferencji został podzielony na dwie części. Pierwsza z nich, plenarna, miała na celu określenie problematyki obrad, druga, panelowa, składała się z trzech sekcji tematycznych. Sesję plenarną otworzył wykład prof. zw. dr hab. Amadeusza Krause, w którym prelegent podjął refleksję nad niefrasobliwą euforią interdyscyplinarności, podkreślając jej szczególną rolę. Następnie dr hab. prof. UAM Marcin Wlazło poruszył 
problematykę interdyscyplinarnych studiów nad niepełnosprawnością, stawiając pytanie, czy są one sprzymierzeńcem, czy wrogiem pedagogiki specjalnej. Z kolei prof. zw. dr hab. Marzenna Zaorska wskazała na specyfikę współczesnej rzeczywistości naukowej, wybrane osiągniecia naukowe w perspektywie pedagogiki specjalnej, a także zastanawiała się, jaka jest przyszłość pedagogiki specjalnej. Następnie prof. zw. dr hab. Iwona Chrzanowska przedstawiła perspektywy demograficzne $65+$ będące wyzwaniem dla pedagogiki specjalnej, podkreślając rolę andragogiki oraz gerontologii specjalnej, a także głównych problemów do przezwyciężania w procesie starości. Część plenarną obrad zamknęło wystąpienie prof. zw. dr hab. Marii Chodkowskiej poruszające problematykę diagnostycznych i aplikacyjnych dymensji problemów niepełnosprawności w kontekście socjologicznej teorii ról społecznych.

Ze względu na różnorodność zgłoszonych wystąpień dalsze obrady odbyły się w trzech równoległych sekcjach ukierunkowanych tematycznie. Pierwsza z nich, prowadzona przez prof. zw. dr hab. Marię Chodkowską i dr Sylwię Wronę, zawierała wystąpienia dotyczące szeroko pojętego społecznego kontekstu funkcjonowania osób z niepełnosprawnością. Jako pierwsza wystąpiła prof. zw. dr hab. Janina Wyczesany, przedstawiając referat dotyczący kontaktu psychicznego i jego roli w pedagogice specjalnej. Następnie prof. dr. hab. Jadwiga Kuczyńska-Kwapisz wskazała wartości niewidomej młodzieży $\mathrm{w}$ aspekcie społecznym i lingwistycznym. Dr hab. prof. UKW Dorota Podgórska-Jachnik swoje wystąpienie poświęciła zagadnieniom dotyczącym Disability studies, dokonując rozważań dotyczących społecznego rodowodu i społecznego zaangażowania. Z kolei $\mathrm{dr}$ hab. Alina Szczurek-Boruta przedstawiła problematykę zaangażowania w zmianę sytuacji społecznej i edukacyjnej osób z niepełnosprawnością, podając kilka uwag z perspektywy pedagogiki społecznej, a także edukacji międzykulturowej. Następnie dr hab. prof. APS Bernadeta Szczupał poświęciła swoje wystąpienie zagadnieniom dotyczącym asystenta osoby z niepełnosprawnością. Dr hab. prof. UP Jolanta Zielińska przedstawiła sprofilowaną i spersonalizowaną rehabilitację pobudzoną (sterowną) danymi. Dr Jerzy Rottermund zwrócił uwagę na zagadnienia dotyczące korzystania z przedmiotów adaptacyjnych poprawiających funkcję ręki podczas przygotowania i spożywania posiłków. Następnie dr hab. prof. UWM Agnieszka Żyta tematem swojego wystąpienia uczyniła samostanowienie osób z niepełnosprawnością będące elementem rehabilitacji. Jako ostatni głos zabrał dr hab. prof. UWM Sławomir Przybyliński, który przedstawił 
wykład dotyczący „cwaniackiej” edukacji instant - będącej portretem osób "nie w pełni sprawnych" społecznie w przestrzeni inkarcerowanej.

Obrady drugiej sekcji prowadzone były przez dr hab. prof. US Marcina Wlazło i dr Magdalenę Bełzę. Jako pierwsza wystąpiła dr hab. prof. UG Sławomira Sadowska, która uczyniła tematem swojego wystąpienia pytanie: kim być powinien pedagog specjalny: granice naruszeń i redukcji wzorca. Następnie dr hab. prof. UP Piotr Majewicz scharakteryzował psychoedukację $\mathrm{w}$ pracy pedagoga specjalnego. Wystąpienie dr hab. prof. UAM Beaty Jachimczak oscylowało wokół problematyki polityki oświatowej wobec ucznia ze specjalnymi potrzebami edukacyjnymi. Dr hab. prof. UWM Urszula Bartnikowska i dr Katarzyna Ćwirynkało przedstawiły wykład dotyczący 25 lat funkcjonowania „nowej” ustawy o systemie oświaty. Następnie dr hab. prof. UP Adam Mikrut poświęcił swoje wystąpienie zagadnieniom dotyczącym edukacji integracyjnej i włączającej, przedstawiając prawo do edukacji w kontekście polskich tłumaczeń konwencji o prawach osób niepełnosprawnych. W dalszej kolejności dr hab. prof. PR Anna Zamkowska przedstawiła zagadnienia dotyczące kształtowania kultury szkoły włączającej w doświadczeniach zagranicznych. Doc. Mgr. Eva Zezulkowa, Ph. D oraz doc. Ph Dr. et Ph Dr. Martin Kaleja, Ph. D. omówili problematykę badan ukierunkowanych na gotowość nauczycieli na inkluzję uczniów ze specjalnymi potrzebami edukacyjnymi. Następnie dr hab. prof. UZ Zdzisława Janiszewska-Nieścioruk poruszyła zagadnienia dotyczące wyłączania włączonych, a także szkoły w roli najsłabszego ogniwa całożyciowej edukacji osób z niepełnosprawnością intelektualną. Dr. hab. prof. UPH Leszek Ploch ukazał istotę podmiotowości w kulturze artystycznej osób z niepełnosprawnością intelektualną. Obrady w tej sekcji zakończyło wystąpienie dr hab. Marka Piotrowskiego, którego motywem przewodnim był E-podręcznik.

Obradom trzeciej sekcji przewodniczyły prof. zw. dr hab. Marzenna Zaorska i dr Dorota Prysak. Pierwszy referat wygłosili dr hab. prof. APS Grzegorz Szumski i dr Joanna Smogorzewska, przedstawiając badania dotyczące rozwoju teorii umysłu $\mathrm{u}$ dzieci $\mathrm{z}$ niepełnosprawnością z uwzględnieniem formy kształcenia. Następnie dr hab. Piotr Gindrich poruszył zagadnienie jakości środowiska dziecka w wieku przedszkolnym jako znanego czy nieznanego pojęcia w teorii i praktyce edukacji specjalnej. Dr hab. prof. UR Krystyna Barłóg poświeciła swoje wystąpienie teorii integracji, empatii, dezintegracji pozytywnej w systemowym ujęciu współczesnej pedagogiki specjalnej. Z kolei prof. dr hab. Anna Nowak poruszyła 
zagadnienie ujęcia teoretycznego wsparcia społecznego kobiet z niepełnosprawnością. Dr hab. prof. DWSE Joanna Kruk-Lasocka oraz mgr Dagmara Lewandowska podjęły rozważania dotyczące Szkoły Demokratycznej jako miejsca przyjaznego dla dziecka z całościowymi zaburzeniami rozwoju. Dr hab. prof. UP Grażyna Gunia omówiła zagadnienia dotyczące interdyscyplinarnej wiedzy o zdrowiu $\mathrm{w}$ edukacji socjalizacji osób $\mathrm{z}$ niepełnosprawnością. Z kolei dr hab. Anna Wojnarska i dr Renata Zubrzycka podjęły problematykę interdyscyplinarności $\mathrm{w}$ diagnozie i terapii chorób alergicznych układu oddechowego dzieci i młodzieży. Następnie dr hab. Stanisława Byra zajęła się zagadnieniem potraumatycznego wzrostu i deprecjacji u osób z nabytą niepełnosprawnością ruchową. Jako ostatnia w tej części obrad wystąpiła dr hab. prof. UP Jolanta Baran, przedstawiając możliwości zastosowania analizy formy narracji matki o dziecku z niepełnosprawnością do oceny postawy i kompetencji rodzicielskich.

Drugi dzień konferencji przebiegał $\mathrm{w}$ tradycyjnej formie obrad w sekcjach tematycznych. Uczestnicy konferencji obradowali w Zespole Szkół Specjalnych nr $4 \mathrm{w}$ Sosnowcu, gdzie zostali powitani serdecznie przez pana dyrektora Pana Arkadiusza Chęcińskiego. Wystąpienia prelegentów, podzielone na osiem sekcji, dotyczyły szerokiej problematyki z zakresu pedagogiki specjalnej, m.in. społecznego funkcjonowania, z uwzględnieniem pozycji społecznej, grupy rówieśniczej, motywacji do nauki szkolnej, tematyki rodziny, różnych form terapii, a także wsparcia społecznego.

Warto zauważyć, że wystąpienia konferencyjne poruszały liczne, istotne zagadnienia zarówno o charakterze empirycznym, jak i teoretycznym, przedstawiono wiele rozwiązań praktycznych $\mathrm{w}$ zakresie terapii, a także szeroko rozumianego wsparcia społecznego. 